\title{
Selected haematological changes in Clarias gariepinus (Burchell, 1822) infected with a Trypansosoma sp. from the Vaal Dam, South Africa
}

\author{
Authors: \\ Maryke L. Ferreira \\ Annemariè Avenant- \\ Oldewage $^{1}$ \\ Affiliations: \\ ${ }^{1}$ Department of Zoology, \\ University of Johannesburg, \\ South Africa \\ Correspondence to: \\ Annemariè Avenant- \\ Oldewage \\ Email: \\ aoldewage@uj.ac.za \\ Postal address: \\ PO Box 524, Auckland Park \\ 2006, South Africa \\ Dates: \\ Received: 04 Feb. 2013 \\ Accepted: 04 May 2013 \\ Published: 13 June 2013 \\ How to cite this article: \\ Ferreira, M.L. \& Avenant- \\ Oldewage, A., 2013, \\ 'Selected haematological \\ changes in Clarias gariepinus \\ (Burchell, 1822) infected with \\ a Trypansosoma sp. from \\ the Vaal Dam, South Africa, \\ Onderstepoort Journal of \\ Veterinary Research 80(1), \\ Art. \#572, 3 pages. \\ http://dx.doi.org/10.4102/ \\ ojvr.v80i1.572

\section{Copyright:} \\ (C) 2013. The Authors. \\ Licensee: AOSIS \\ OpenJournals. This work \\ is licensed under the \\ Creative Commons \\ Attribution License. \\ Read online:

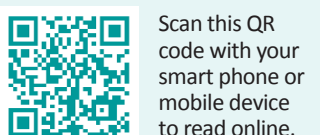

The use of haematological techniques to assess fish health is generally accepted. The aim of the current study was to determine selected haematological changes that occur in Clarias gariepinus (Burchell, 1822). infected with trypanosomes. Blood films were prepared according to standard techniques to confirm trypanosome infections and whole blood was collected, the serum and plasma separated, and prepared for albumin and total protein concentration analysis. Plasma albumin levels were significantly higher in infected wild caught fish than in uninfected wild caught fish and uninfected breeding stock. Serum albumin levels were significantly lower in infected wild caught fish when compared to uninfected breeding stock. The total plasma and serum protein levels were within the normal range for C. gariepinus, that is, $3 \mathrm{~g}-6 \mathrm{~g} / 100 \mathrm{~mL}$. The total plasma protein levels varied significantly between the three groups. However, the total serum protein levels were only significantly different between uninfected breeding stock and uninfected wild caught fish, as well as uninfected breeding stock and infected wild caught fish. The total protein levels were significantly higher in infected wild caught fish than in the other groups, a possible indication of an infection or inflammatory host response.

\section{Introduction}

To date, approximately 200 species of piscine trypanosomes are known (Gupta \& Gupta 2012). In nature, trypanosome infections are common, especially where the leech vector is abundant. The effect of a trypanosome infection depends solely upon the host's energy resources, and the impact ranges from physiological (Tandon \& Chandra 1977), metabolic, pathological (Lom \& Dykova 1984), biochemical (Gupta \& Gupta 1986) and asymptomatic, to behavioural anomalies and syndromes (Barber, Hoare \& Krause 2000). Haematological techniques are important for the assessment of the impact of trypanosome infections on fish health (Shah \& Altindağ 2004). Osman, Fadel and Ali (2009) reported that Clarias gariepinus (Burchell, 1822) infected with Trypanosoma mukasai Hoare, 1932 showed significant decreases in total serum protein, albumin, globulin levels, albumin/globulin ratios and cholesterol concentrations. These authors also noted an increase in serum aspartate aminotransferase and alanine aminotransferase enzyme activities. However, no significant effect was noted for serum urea, creatinine and uric acid concentrations (see Osman et al. 2009). Gupta and Gupta (2012) recorded erythropenia due to piscine trypanosomiasis in various fish hosts. Symptoms of piscine trypanosomiasis range from anaemia (Woo 1981; Islam \& Woo 1991) to leucocytosis, hypoglycaemia and hypocholesterolemia (Gupta \& Jairajpuri 1983; Gupta \& Gupta 1986). Several authors have reported on the effect of trypansome infection on albumin (Osman et al. 2009; Kharat \& Kothawade 2012; Kovyrshina \& Rudneva 2012) and total protein levels (MLay et al. 2007; Osman et al. 2009; Kharat \& Kothavade 2012). According to Gupta and Gupta (2012), increased erythroblasts, haemoblasts and macrophages can also occur as clinical manifestations. The aim of the current study is to determine whether any haematological changes occur in the African sharptooth catfish, C. gariepinus infected with trypanosomes.

\section{Materials and methods}

Twenty-one C. gariepinus were collected from the Vaal Dam (2652.249'S $\left.28^{\circ} 10.249^{\prime} \mathrm{E}\right)$, South Africa, using gill nets. The fish were kept in fully prepared aquaria. Non-infected C. gariepinus breeding stock were maintained at the University of Johannesburg aquarium, South Africa. Blood films were prepared from all fish. Infections were confirmed by observing haemoflagellates in methanol fixed and Giemsa stained films prepared according to the method described by Davies et al. (2005). Blood samples were collected from both trypanosoma infected (wild caught) and non-infected (wild caught and breeding stock) fish and centrifuged to concentrate cellular components. Serum was obtained by allowing blood to clot for $30 \mathrm{~min}-45 \mathrm{~min}$ (yielding serum without fibrinogen) and then centrifuged at $3000 \mathrm{rpm}$ for $15 \mathrm{~min}$. In a duplicate set, the plasma 
was separated by centrifuging unclotted blood at $3000 \mathrm{rpm}$ for $10 \mathrm{~min}$. Plasma and serum were respectively transferred to separate Eppendorf tubes and stored in liquid nitrogen until further examination. Samples were thawed at room temperature. BCG albumin (DIAG-250) and total protein (QCPR-500) values were measured following standard operating procedures supplied by BIOCOM biotech. Data are presented as mean \pm standard error. A two-way analysis of variance (ANOVA) was done to calculate any significant differences between infected and uninfected groups using Graph Pad prism 6, version 6.01, significance was set at 95\%.

\section{Results}

The trypanosomes in C. gariepinus blood films resemble T. mukasai. Morphological characteristics include a nucleus anterior to the mid-line, similar to the descriptions of Baker (1960), Negm-Eldin (1997), Smit, Davies and Van As (2000) and Ferreira and Avenant-Oldewage (2013). Of the 21 C. gariepinus collected from the Vaal Dam, only 19\% (4/21) were infected. Parameters between plasma and serum were similar (Table 1). Significant differences $(p<0.05)$ were noted between albumin and total plasma protein levels. The twoway ANOVA indicated significant differences between plasma albumin levels between uninfected breeding stock and infected wild caught fish, as well as between uninfected wild caught fish and infected wild caught fish (Table 1). Serum albumin levels differed significantly between uninfected breeding stock and uninfected wild caught fish, as well as between uninfected breeding stock and infected wild caught fish (Table 1). Significant differences in the total plasma protein were seen between all three groups of fish, although total serum protein differed significantly only between uninfected breeding stock and uninfected wild caught fish, uninfected breeding stock and infected wild caught fish, and uninfected wild caught and infected wild caught fish. Total protein in uninfected wild caught fish was significantly higher than in uninfected wild caught fish or uninfected breeding stock fish serum and plasma.

It was also noted that some of the fish collected from the Vaal Dam and Vaal Barrage were infected with Proteocephalus glanduligerus (Janicki, 1928), Tetracampos ciliotheca (Wedl, 1861) and unidentified nematodes, and the parasitemia in these fish was very low. The presence of cestodes was previously recorded from this locality (Madanire-Moyo \& Avenant-Oldewage 2013).

\section{Discussion}

Blood parameters are patho-physiological indicators of the whole body and are thus important in diagnosing the health status of fish (Maheswaran et al. 2008). The albumin concentration in fish plasma and serum reflects the health of the animal, liver function, metabolic status and stress conditions (Kovyrshina \& Rudneva 2012). Plasma albumin levels were significantly higher (Table 1) in trypanosome infected wild caught fish than in uninfected wild caught and uninfected breeding stock. The lowest levels were observed in uninfected fish reared as breeding stock. In a study done by Kharat and Kothawade (2012) on the haematology of Clarias batrachus (Linnaeus, 1758) with trypanosomosis, higher levels of albumin were reported in infected fish. However, these levels were not significantly different from those of uninfected fish. Osman et al. (2009) reported low serum albumin levels in trypanosome-infected C. gariepinus, which resulted in generalised oedema and haemodilution. In the current study, serum albumin levels were significantly lower for infected wild caught fish when compared to uninfected breeding stock, indicating haemodilution caused by the trypanosome infection. Parasite infection is most likely not the only factor responsible for variation in albumin levels, since it has been noted that diet composition (Chukwuma, Obioma \& Christopher 2010; McQueen et al. 2011; Kovyrshina \& Rudneva 2012), fish species, age, life cycle stage, sexual maturity, health and environmental factors (Kovyrshina \& Rudneva 2012) also affect albumin levels. Thus the high albumin levels observed in uninfected breeding stock may also be attributed to their diet and/or their age (Hasnain et al. 2004).

Low plasma protein levels are often linked to starvation and depletion of energy stores (Lockhart \& Metner 1984; Cunjak 1988). Plasma proteins include globulins, fibrinogens and albumins, and are vital in transporting materials via the circulation system (Inyang, Daka \& Ogamba 2010). Adams, Brown and Goede (1993) recorded the normal range for total protein to be between $3 \mathrm{~g}-6 \mathrm{~g} / 100 \mathrm{~mL}$ and Adeyemo et al. (2003) recorded the reference value to be $3.8 \mathrm{mg} \pm 0.11 \mathrm{mg} / 100 \mathrm{~mL}$. In the current study, total protein values for all groups were within the range proposed by Adams, Brown and Goede (1993) (Table 1). Uninfected breeding stock levels (plasma and serum) were the lowest, indicting depletion of energy stores (Table 1). Fish infected with trypanosomes had a higher total protein plasma and/or serum levels. According to Khan (1977, 1980), a decrease in plasma protein is associated with trypanosome infections. This was also noted by Smirnova (1970) for serum protein levels of burbot, Lota lota (Linnaeus, 1758), infected with Trypanosoma lotae (Smirnova, 1970) and similarly by Tandon \& Joshi (1973) for fish infected with Trypanosoma

TABLE 1: Clarias gariepinus (Burchell, 1822) collected from the Vaal Dam, South Africa haematological parameters tested.

\begin{tabular}{|c|c|c|c|c|c|c|}
\hline \multirow[t]{2}{*}{ Biological Parameters } & \multicolumn{3}{|c|}{ Plasma } & \multicolumn{3}{|c|}{ Serum } \\
\hline & UNB $(n=10)$ & UNW $(n=17)$ & INW $(n=4)$ & UNB $(n=10)$ & UNW $(n=17)$ & INW $(n=4)$ \\
\hline BCG Albumin (g/dL) & $0.341 \pm 0.002^{\mathrm{a}}$ & $0.342 \pm 0.001^{b}$ & $0.348 \pm 0.005^{a b}$ & $0.342 \pm 0.002^{\mathrm{ab}}$ & $0.333 \pm 0.001^{a}$ & $0.334 \pm 0.001^{b}$ \\
\hline Total Protein $(\mathrm{g} / 100 \mathrm{~mL})$ & $5.111 \pm 0.085^{a}$ & $5.321 \pm 0.045^{a}$ & $5.467 \pm 0.085^{a}$ & $4.966 \pm 0.045^{a}$ & $5.167 \pm 0.052^{b}$ & $5.182 \pm 0.046^{\mathrm{ab}}$ \\
\hline
\end{tabular}

UNB, Uninfected Breeding Stock; UNW, Uninfected Wild Caught; INW, Infected Wild Caught; ${ }^{\text {a }}$, indicates significant differences between two groups; ${ }^{\text {b }}$ indicates significant differences between two or more groups; ${ }^{\mathrm{ab}}$, indicates significant differences noted between ' $a$ ' and ' $b$ '.

$n=$ number of fish collected.

Each value represents mean \pm standard error means. Significant differences between parameters and infected/non-infected classes $(p<0.05)$ are indicated with superscript within columns

Example: BCG Albumin ( $\mathrm{g} / \mathrm{dL}$ ) plasma levels significant difference between UNB and INW (indicated with superscript a); and between UNW and INW (indicated with superscript b). 
vittati (Tandon \& Joshi, 1973) and Trypanosoma maguri (Tandon \& Joshi, 1973).

\section{Conclusion}

Wild fishes are frequently infected with a variety of pathogens and are regularly subjected to various stress factors, thus it is difficult to assign abnormalities to any one particular cause (Woo 2006). Future studies should include assessment of other parasites (internal and external) to exclude their effect on blood parameters. Hence the present study should be seen as preliminary.

\section{Acknowledgements}

The University of Johannesburg is thanked for providing infrastructure and funding to Annemariè Avenant-Oldewage.

\section{Competing interests}

The authors declare that they have no financial or personal relationship(s) that may have inappropriately influenced them in writing this article.

\section{Author's contributions}

M.L.F. (University of Johannesburg) was a post-doctorate student and performed analysis on blood and provided the first draft of the manuscript. A.A-O. (University of Johannesburg) was the supervisor and provided input on various drafts of manuscript.

\section{References}

Adams, S.M., Brown, A.M. \& Goede, R.W., 1993, 'A quantitative Health Assessment Index for rapid evaluation of fish condition in the field', Transactions of the American Fisheries Society 122, 63-73.

Adeyemo, O.K., Agbede, S.A., Olaniyan, A.O. \& Shoag, O.A., 2003, 'The haematological response of Clarias gariepinus to changes in acclimation temperature', African Journal of Biomedical Research 6, 105-108.

Baker, J.R., 1960, 'Trypanosomes and dactylosomes from the blood of freshwater fishes in East Africa', Parasitology 51, 515-526.

Barber, I., Hoare, B. \& Krause, J., 2000, 'Effects of parasites on fish behavior: A review and evolutionary perspective', Reviews in Fish Biology and Fisheries 10, 13-165.

Chukwuma, E.R., Obioma, N. \& Christopher, O.I., 2010, 'The phytochemical composition and some biochemical effects of Nigerian tigernut (Cyperus esculentus L.) tuber', Pakistan Journal of Nutrition 9, 709-715.

Cunjak, R.A., 1988, 'Physiological consequences of overwintering in streams: The cost of acclimatisation?', Canadian Journal of Fisheries and Aquatic Science 25 443-452.

Davies, A.J., Gibson, W., Ferris, V., Basson, L. \& Smit, N.J., 2005, 'Two genotypic groups of morphologically similar fish trypanosomes from the Okavango Delta, Botswana', Diseases of Aquatic Organisms 66, 215-220.

Ferreira, M.L. \& Avenant-Oldewage, A., 2013, 'Notes on the occurrence of Trypanosoma sp. (Kinetoplastida: Trypanosomatidae) in freshwater fishes from South Africa', Onderstepoort Journal of Veterinary Research 80, http://dx.doi. org/10.4102/ojvr.v80i1.529

Gupta, N. \& Gupta, D.K., 1986, 'Trypanosome infectivity and changes in the glucose level of two freshwater fishes', Indian Journal of Parasitology 10, 213-215.
Gupta, N. \& Gupta, D.K., 2012, 'Erythropenia in piscine trypanosomiasis', Trends in Parasitology 1, 1-6.

Gupta, N. \& Jairajpuri, D.S., 1983, 'Trypanosoma batrachi Qadri, 1962 and its effect on the biochemical composition of the blood of Clarias batrachus', Acta Protozoologica 22, 79-85.

Hasnain, A., Ahmad, R., Jabeen, M. \& Khan, M.M., 2004, 'Biochemical characterization of a protein of albumin multigene family from serum of African catfish Clarias gariepinus Bloch', Indian Journal of Biochemistry and Biophysics 41, 148-153.

Inyang, I.R., Daka, E.R. \& Ogamba, E.N., 2010, 'Effects of sub-lethal concentrations of diazinon on total protein and transaminase activities in Clarias gariepinus', Current Research Journal of Biological Sciences 2, 290-295.

Islam, A.K.M.N. \& Woo, P.T.K., 1991, 'Anemia and its mechanism in goldfish Carassius auratus infected with Trypanosoma danilewskyi', Diseases of Aquatic Organisms $11,37-44$.

Khan, R.A., 1977, 'Blood changes in Atlantic Cod (Gadus morhua) infected with Trypanosoma murmanensis', Journal of Fisheries Research Board of Canada 34 2193-2196.

Khan, R.A., 1980, 'The leech as a vector of a fish piroplasm', Canadian Journal of Zoology 58, 1631-1637.

Kharat, S. \& Kothawad, S., 2012, 'Haematological study of Clarias batrachus with reference to trypanosomiasis', Trends in Fisheries Research 1, 6-9.

Kovyrshina, T.B. \& Rudneva, I.I., 2012, 'Comparative study of serum albumin levels in round goby Neogobius melanostomus from Black Sea and Azov Sea', International Journal of Advanced Biological Research 2, 203-208.

Lockhart, W.L. \& Metner, D.A., 1984, 'Fish serum chemistry as a pathological tool', in. V.W. Cairs, P.V. Hodson \& J.O. Nriagu (eds.). Contaminant effects on fisheries, p. 73-85, Wiley, New York.

Lom, J. \& Dykova, I., 1984, 'Pathogenecity of some protozoan parasites of cyprinid fishes', in J. Olah (ed.), Fish, pathogens and environment in European polyculture,
proceedings of an international seminar on fish pathogens and environment in proceedings of an international seminar on fish pathogens and environment in
European polyculture, 23-27 June 1981, Szarvas, Hungary. Symposia Biologica European polyculture,
Hungarica 23, 99-118.

Madanire-Moyo, G. \& Avenant-Oldewage, A., 2013, 'Occurrence of Tetracampos ciliotheca and Proteocephalus glanduligerus in Clarias gariepinus (Burchell, 1822) collected from the Vaal Dam, South Africa', Onderstepoort Journal of Veterinary

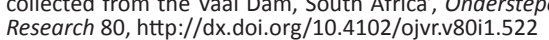

Maheswaran, R., Devapanl, A., Muralidharan, S., Velmurugan, B. \& Ignaeimuthu, S., 2008, 'Haematological studies of fresh water fish, Clarias batracus (L) exposed to mercuric chloride', International Journal of Integrated Biology 2, 49-54.

McQueen, H.A., Wassif, W.S,. Walker, I., Sadler, D.A. \& Evans, K., 2011, 'Age-related biomarkers can be modulated by diet in the rat', Food and Nutrition Sciences 2 , $884-890$

MLay, P.S., Seth, M., Balthazary, S.T., Chiunda, R.T., Phiri, E.C.J.H. \& Balemba, O.B., 2007, 'Total plasma proteins and hemoglobin levels as affected by worm burden in freshwater fish in Morogoro, Tanzania', Livestock Research for Rural Development 19, 1-8.

Negm-Eldin, M.M., 1997, 'Trypanosoma mukasai (Hoare, 1932) in its biological vector Batracobdelloides tricarinata (Blanchard, 1897) and their life cycles', Deutsche Tierärztliche Wochenschrift 104, 215-219.

Osman, H.A.M., Fadel, N.G. \& Ali, A.T., 2009, 'Biochemical and histopathological alterations in catfish, Clarias gariepinus infected with trypanosomiasis with special reference to immunization' Egypt Journal of Comparative Pathology and Clinical Pathology 22, 164-181.

Shah, S.L. \& Altindağ, A., 2004, 'Hematological parameters of tench (Tinca tinca L.) after acute and chronic exposure to lethal and sublethal mercury treatments', Bulletin of Environmental Contamination and Toxicology 37, 911-918.

Smirnova, L.I., 1970, 'Trypanosoma in the blood of Lota lota L. (Trypanosoma lotae sp.n.)', Parazitologiya 4, 296-297.

Smit, N.J., Davies, A.J. \& Van As, J.G., 2000, 'A trypanosome from the silver catfish (Schilbe intermedius) in the Okavango Delta, Botswana' Bulletin of the European Association of Fish Pathologists 20, 116-119.

Tandon, R.S. \& Chandra, S., 1977, 'Physiology of host parasite relationship: effect on serum alkaline phosphatase levels of fish hosts parasitized by trypanosomes' Zeitschrift für Parasitenkunde 52, 195-198.

Tandon, R.S. \& Joshi, B.D., 1973, 'Studies on the physiopathology of blood of freshwater-fishes infected with two new forms of trypanosomes', Zeitschrift für Wissenschaftliche Zoologie 185, 207-221.

Woo, P.T.K., 1981, 'Acquired immunity against Trypanosoma danilewskyi in goldfish, Carassius auratus', Parasitology 83, 343-346.

Woo, P.T.K., 2006, 'Diplomanodida (Phylum Parabasalia) and Kinetoplastea (Phylum Euglenozoa)', in Fish diseases and disorders, vol. 1, Protozoan and metazoan infections 2nd edn., p. 17-115, CABI Publishing, Wallingford. 